\title{
Erratum: Environmental change and long-term body mass declines in an alpine mammal
}

\author{
Tom HE Mason ${ }^{1 *}$, Marco Apollonio ${ }^{2}$, Roberta Chirichella ${ }^{2}$, Stephen G Willis ${ }^{1}$ and Philip A Stephens ${ }^{1}$
}

\section{Erratum}

There is an inconsistency between the sample size quoted in the Methods section and that presented in Additional file 1 [1]. The number quoted in the Methods of 10,455 individuals (5,762 males and 4,693 females) is incorrect. This figure relates to our full database, which includes some individuals shot beyond the boundaries of the areas focused on in this study. Because those individuals came from areas with limited representation in the database, they were excluded from our analysis. Following their exclusion, our sample size was 9,388 individuals (5,218 males and 4,170 females, as displayed in Additional file 1); this is the number that should have been quoted in the main text. Importantly, since the excluded data were removed before we conducted our analysis, our results and conclusions are unchanged. We apologise for any potential confusion this may have caused.

\footnotetext{
Author details

${ }^{1}$ School of Biological and Biomedical Sciences, Durham University, South Road, Durham DH1 3LE, UK. ${ }^{2}$ Department of Science for Nature and Environmental Resources, University of Sassari, via Muroni 25, Sassari I-07100, Sardinia, Italy.
}

Received: 20 November 2014 Accepted: 20 November 2014

Published online: 05 December 2014

\section{References \\ 1. Mason TH, Apollonio M, Chirichella R, Willis SG, Stephens PA: Environmental change and long-term body mass declines in an alpine mammal. Front Zool 2014, 11:69.}

doi:10.1186/s12983-014-0088-3

Cite this article as: Mason et al:: Erratum: Environmental change and

long-term body mass declines in an alpine mammal. Frontiers in Zoology 2014 11:88.

\section{Submit your next manuscript to BioMed Central and take full advantage of:}

- Convenient online submission

- Thorough peer review

- No space constraints or color figure charges

- Immediate publication on acceptance

- Inclusion in PubMed, CAS, Scopus and Google Scholar

- Research which is freely available for redistribution 